Discussion Paper No. 08-058

\title{
A Lead Market Approach Towards the Emergence and Diffusion of Coal-fired Power Plant Technology
}

Klaus Rennings and Wilko Smidt

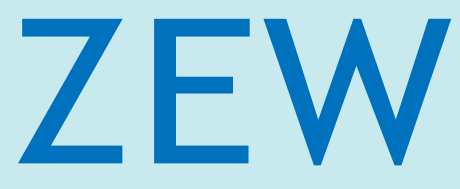

Zentrum für Europäische Wirtschaftsforschung $\mathrm{GmbH}$

Centre for European

Economic Research 
Discussion Paper No. 08-058

\section{A Lead Market Approach Towards the Emergence and Diffusion of Coal-fired Power Plant Technology}

Klaus Rennings and Wilko Smidt

Download this ZEW Discussion Paper from our ftp server:

ftp://ftp.zew.de/pub/zew-docs/dp/dp08058.pdf

Die Discussion Papers dienen einer möglichst schnellen Verbreitung von neueren Forschungsarbeiten des ZEW. Die Beiträge liegen in alleiniger Verantwortung der Autoren und stellen nicht notwendigerweise die Meinung des ZEW dar.

Discussion Papers are intended to make results of ZEW research promptly available to other economists in order to encourage discussion and suggestions for revisions. The authors are solely responsible for the contents which do not necessarily represent the opinion of the ZEW. 


\section{Non-technical summary}

Today, more than $70 \%$ of the world's total electricity production is supplied by power plants using conventional fossil fuels. Coal accounts for more than half of the fossil fuel combustion in electricity plants. Five mega trends in the future - a growing world population, urbanisation, an increasing world GDP, increasing economic power in India and China - give reason to believe that electricity demand will double until 2030. The abundance of coal reserves in many countries and increasing fuel prices for gas and oil against the background of a growing need to provide sufficient, secure and affordable energy make coal an attractive option in worldwide electricity production.

The estimated annual market volume of electricity plants powered by fossil fuels is $\$ 208 \mathrm{bn}$. A great share of this market volume is destined for coal-fired power plant technology. However, the need to reduce $\mathrm{CO}_{2}$ emissions in order to stop climate change has made coal combustion a central subject to environmental discussions. Many countries have already begun to develop "clean coal technologies" and have started to diffuse these technologies in domestic markets. Despite the fact that clean coal technologies are already present and are currently adopted by many countries, the penetration rate differs considerably from country to country.

The aim of this paper is to analyse why clean coal technologies in some countries diffuse faster and to a greater extent than in other nations. The paper applies the lead market concept in order to test the practicability of the methodology. Lead markets are markets that adopt an innovation before it is adopted by most other countries and therefore lead the global diffusion of the innovation.

The most important technological trajectory for coal power plants is the pulverised coal-fired steam cycle (PC) which is the basis for all other coal combustion technologies. Modern PC technology is well developed and accounts for over $90 \%$ of coal-fired capacity worldwide. Therefore it will be taken as a reference technology for this paper, with SC (Supercritical) coal-fired power generation technologies being selected as an innovative technology within this trajectory. Moreover, SC technology has diffused over sufficiently long time periods to be examined by ex post analysis. As for the diffusion of SC, the paper concentrates on Germany, USA, China and Japan.

The analysis of the diffusion curves of SC technology shows that the typical lead market pattern applies only to a limited extent. In the 1960s and 1970s, the USA established a lead 
market for SC technology; diffusion rates were high and large numbers of SC units were built. Other countries adopted the American innovation design, but when the USA stopped building supercritical coal-fired power plants in the late 1970s, the picture changed and diffusion curves overlapped, which is unusual. Japan surpassed the United States, although they started out as typical lag markets in the early 1980s. Japanese companies manage to meet their demand almost entirely out of domestic production and American technology plays only a minor role in both countries.

Generally, countries that are the first to widely diffuse an innovation design in the domestic market become lead markets. So far, the lead market model argues that lead markets do not switch to other countries but are "stable". This has been supported by several empirical analyses regarding, for instance, the diffusion of cellular phones, facsimile machines, diesel motors with direct injection, etc. Here we might see a clear deviation from that rule, since at least the diffusion curves overlap. After analysing the technology diffusion in the four countries, the question evolves: Can we determine a lead market for coal-fired power plant technology today? A closer look at the different lead market factors gives us the following answer: It can be concluded from the discussion of lead market factors that currently no clear lead market exists for coal-fired power plant technology. Although the United States still has comparative advantages in terms of prices, demand and market structure, Japan has caught up in terms of transfer advantage and Germany in terms of regulation. In the near future, demand advantages will switch to China.

This supports also the thesis that - apart from the demand-oriented lead market model - push factors such as R\&D activity play a strong role for establishing lead markets as well. The transfer advantage of Japan stems mainly from its intensive R\&D activities. Thus it can be concluded that a mix of push and pull policies is necessary in order to establish a lead market position. 


\section{Das Wichtigste in Kürze}

Heute wird mehr als 70 Prozent der globalen Elektrizitätsproduktion mit fossilen Energieträgern erzeugt. Dabei entfällt mehr als die Hälfte der fossilen Verbrennung auf Kohle. Die fünf Megatrends der Zukunft - wachsende Weltbevölkerung, Verstädterung, wachsende Weltwirtschaft, steigende ökonomische Bedeutung von Indien und China - lassen die Aussichten auf eine Verdopplung der Energienachfrage bis zum Jahre 2030 plausibel erscheinen. Die Verfügbarkeit von Kohlereserven in vielen Ländern und steigende Brennstoffpreise für Gas und Öl machen Kohle zu einer attraktiven Option in der weltweiten Elektrizitätsproduktion, vor allem vor dem Hintergrund eines wachsenden Bedürfnisses nach einer Versorgung mit ausreichender, sicherer und preisgünstiger Energie.

Das geschätzte jährliche Marktvolumen von fossil erzeugter Elektrizität beträgt $208 \mathrm{Mrd}$. \$. Ein großer Teil dieses Marktvolumens ist für kohlebefeuerte Kraftwerkstechnologie bestimmt. Die klimapolitische Notwendigkeit der Reduktion von $\mathrm{CO}_{2}$-Emissionen macht die Kohleverbrennung jedoch zu einem zentralen Gegenstand der Umweltdiskussion. In vielen Ländern wurde bereits mit der Entwicklung von sogenannten sauberen Kohletechnologien begonnen. Die Penetrationsrate dieser Technologien unterscheidet sich aber beträchtlich von Land zu Land.

Das Ziel dieses Papiers ist es, mit Hilfe des Lead-Markt-Konzeptes zu analysieren, warum sich saubere Kohletechnologien in einigen Länder schneller und in einem höheren Ausmaß ausbreiten als in anderen Ländern. Lead-Märkte sind Märkte, die einen zeitlichen Vorsprung bei der Einführung eines Innovationsdesigns besitzen und daher die globale Diffusion anführen. In Bezug auf Kohletechnologien wird das Innovationsdesign der superkritischen Kohlekraftwerke (SC) ausgewählt, da es rund 90\% des Kohlemarktes abdeckt und der Diffusionsverlauf über hinreichend lange Zeiträume, d.h. über einige Jahrzehnte, beobachtbar ist. Das Papier analysiert die Diffusionsverläufe der Innovationsdesigns in Deutschland, den USA, China und Japan.

Die Analyse der Diffusionskurven von superkritischen Kohlekraftwerken zeigt, dass das typische Muster von Lead-Märkten nur bedingt übertragbar ist. Die USA scheinen in den 1960er und 1970er Jahren eine Lead-Markt-Position einzunehmen. Die Diffusionsraten waren hoch und eine große Anzahl von SC-Kraftwerken wurde gebaut. Andere Länder folgten dem amerikanischen Innovationsdesign, aber das Bild ändert sich, als die USA in den späten 1970ern den Bau von SC-Kraftwerken beenden und sich die Diffusionskurven schneiden. Japan überholt Deutschland und die USA, obwohl es als ein typischer Lag-Markt in den 
frühen 1980ern startete. Japanische Firmen decken ihren Bedarf vornehmlich aus heimischer Produktion, amerikanische Technologie spielt nur eine untergeordnete Rolle.

Im Allgemeinen geht der Lead-Markt-Ansatz davon aus, dass Lead-Märkte im Zeitablauf stabil sind und sich die Diffusionskurven insofern nicht schneiden dürften. Nach Analyse der Technologiediffusion von SC-Kohlekraftwerken in den verschiedenen Ländern stellt sich die Frage, ob ein Lead-Markt für dieses spezifischen Technologien bestimmt werden kann. Nach Berücksichtigung der Lead-Markt-Faktoren lässt sich die Schlussfolgerung ziehen, dass gegenwärtig kein Lead-Markt existiert. Während die USA über relative Preis-, Nachfrage und Marktstrukturvorteile verfügen, weist Japan einen Transfervorteil und Deutschland einen Regulierungsvorteil auf. Künftig wird der Nachfragevorteil vermutlich an China fallen.

Dieses Resultat stützt auch die These, dass - jenseits des nachfrageorientierten Lead-MarktModells - auch Push-Faktoren wie zum Beispiel die F+E-Aktivitäten eines Landes eine wichtige Rolle bei der Bestimmung von Lead-Märkten spielen. Denn der Transfervorteil der Japaner ist vor allem aus ihren intensiven F+E-Aktivitäten abzuleiten. Insofern kann geschlussfolgert werden, dass ein Mix aus Push- und Pull-Strategien notwendig ist, um eine Lead-Markt-Position im Bereich von Kohlekraftwerkstechnologien aufzubauen. 


\title{
A lead market approach towards the emergence and diffusion of coal-fired power plant technology
}

\author{
Klaus Rennings, Centre for European Economic Research (ZEW), Mannheim ${ }^{1}$ \\ Wilko Smidt, University of Flensburg
}

\section{Executive summary}

Today, more than $70 \%$ of the world's total electricity production is supplied by power plants using conventional fossil fuels. Coal accounts for more than half of the fossil fuel combustion in electricity plants. Future mega trends give reason to believe that electricity demand will double until 2030. The abundance of coal reserves in many countries and increasing fuel prices for gas and oil against the background of a growing need to provide sufficient, secure and affordable energy make coal an attractive option in worldwide electricity production.

Against this background, the aim of this paper is to analyse why clean coal technologies in some countries diffuse faster and to a greater extent than in other nations. The paper applies the lead market concept. Lead markets are markets that adopt an innovation before it is adopted by most other countries and therefore lead the global diffusion of the innovation.

The most important technological trajectory for coal power plants is the pulverised coal-fired steam cycle (PC) which is the basis for all other coal combustion technologies. Modern PC technology is well developed and accounts for over $90 \%$ of coal-fired capacity worldwide. Therefore it will be taken as a reference technology, with SC (Supercritical) coal-fired power generation technologies being selected as an innovative technology within this trajectory. As for the diffusion of SC, the paper concentrates on Germany, USA, China and Japan.

The analysis shows that the typical lead market pattern applies only to a limited extent. In the 1960s and 1970s, the USA has established a lead market for SC technology. In the meanwhile, Japan has surpassed the United States, although it started out as typical lag market.

After analysing the technology diffusion in the four countries, one central question evolves: Can we determine a lead market for coal-fired power plant technology today? The discussion of lead market factors shows that currently no clear lead market exists for coal-fired power plant technology. Although the United States still has comparative advantages in terms of prices, demand and market structure, Japan has caught up in terms of transfer advantage and Germany in terms of regulation. In the near future, demand advantages will switch to China. This supports also the hypothesis that - apart from the demand-oriented lead market model push factors such as R\&D activity play a strong role as well. The transfer advantage of Japan stems mainly from its intensive R\&D activities. Thus it can be concluded that a mix of push and pull policies is necessary in order to establish a lead market position.

JEL Classification: Q 50, L 50, O 33

Keywords: Lead Markets, Coal Power plants, Energy Technology, Energy Policy

\footnotetext{
${ }^{1}$ Corresponding author: E-Mail: rennings@zew.de
} 


\section{Introduction}

Today, more than $70 \%$ of the world's total electricity production is supplied by power plants using conventional fossil fuels. The worldwide demand for electricity will almost double until 2030. Fossil fuels will continue to provide the greatest share (WEC 2007, p.2). Energy security is of great importance for most countries. Since many countries have abundant coal reserves, coal is believed to provide the desired security in supply (WEC 2007, p.2). Forecasts of a substantial increase in natural gas and oil prices within the next decade as well as a worldwide decreasing use of oil for power generation cause coal to experience resurgence in electricity production once again. The great trends of urbanisation, population growth, globalisation and an increasing world GDP will result in major challenges concerning the provision of electricity. While currently 1.6 billion people have no access to electricity and 2.4 billion rely on primitive biomass fuels for cooking and heating, in the $21^{\text {st }}$ century the world faces critical challenges of providing abundant, cheap electricity. Other than gas and oil, coal is plentiful and available at low costs in many regions of the world. As coal has helped to industrialise many countries in the last two centuries, the developing countries, especially in Asia, regard the burning of coal as a suitable way to foster their economic growth. However, the inconsiderate burning of coal and other fossil fuels has become a major environmental issue. Since its $\mathrm{CO}_{2}$ emission levels are high compared to other power generation options, coal combustion is a central subject of environmental discussions. The need to reduce $\mathrm{CO}_{2}$ emissions stimulates a growing interest in clean coal technology. Besides the theoretical possibility of carbon capture and storage, improving power plant efficiency is the only concrete option when looking for low-emission coal-fired power plants. Many countries have already begun to develop "clean coal technologies" and have pushed the degree of efficiency substantially. However, the market penetration rates of efficient coal-fired power plant technologies differ considerably from country to country. Figure 1 shows the net efficiency of the hard coal power plant fleet of selected countries.

The question that arises is why high-efficient power plant technology diffuses faster in certain countries than in others? Apparently, special circumstances in countries either expedite or suppress the adoption of efficient technology.

This paper analyses the diffusion rates of selected clean coal technologies for China, Germany, Japan and the USA in order to find answers to these questions. In addition, we will try to detect the conditions a country needs to fulfil in order to have comparative advantages 
over other nations concerning the diffusion of innovative power plant technology.

Figure 1: Efficiency of the electricity sector powered by hard coal in selected countries

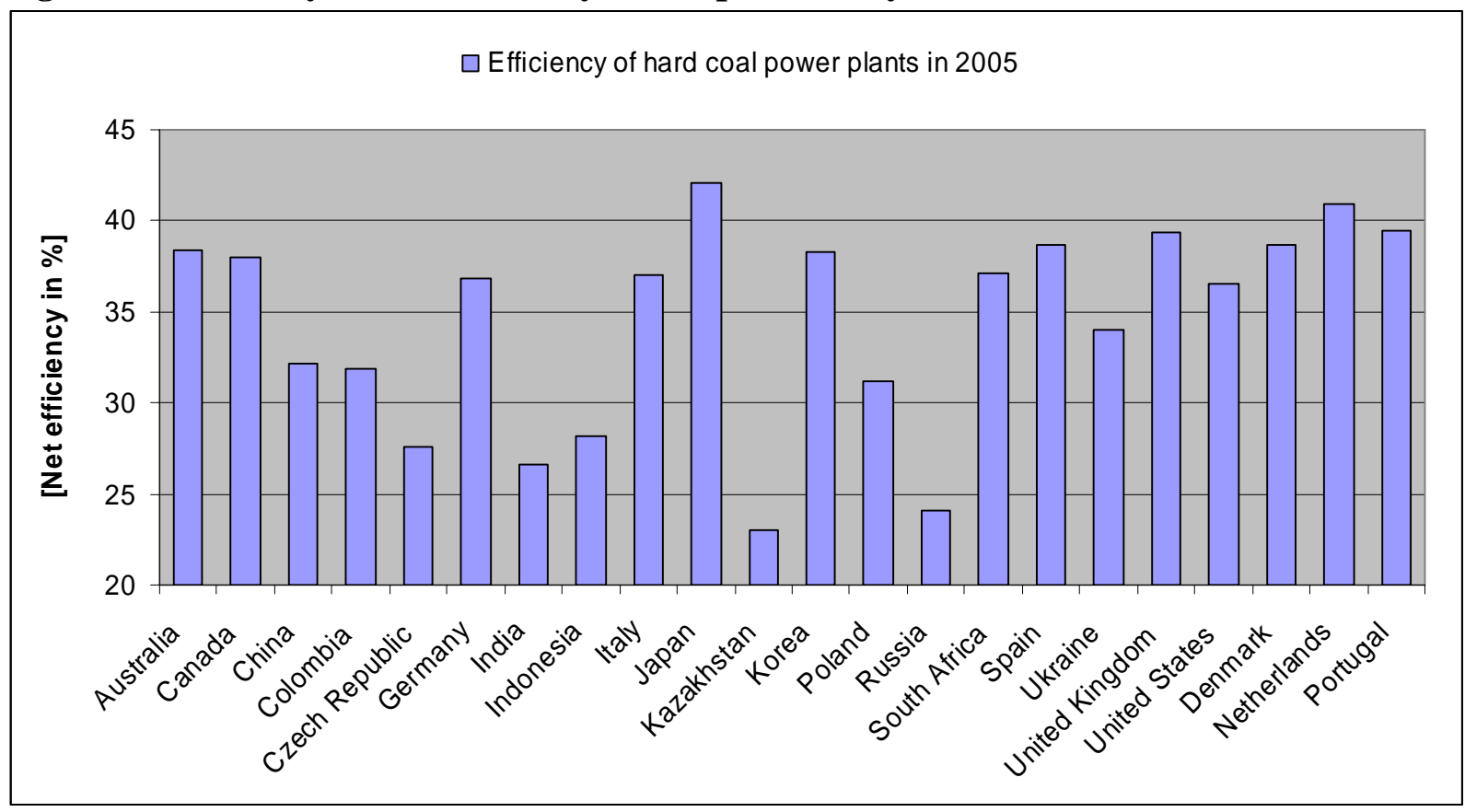

Source: IEA 2007a

The paper is structured as follows: In Section 2 background information on coal as fuel for power generation is given and the examined technology is selected. Section 3 introduces the lead market concept. The actual application of the lead market model to the selected technology is carried out in Section 4. The discussion of the lead market with regard to coalfired power plant technology is presented in section 5. Section 6 draws some conclusions.

\section{Coal combustion technology}

\subsection{Coal as a fossil fuel}

Modern life is unimaginable without electricity. Whether it is used to light houses, buildings, streets, provide domestic and industrial heat or power home, office and industrial equipment, electricity is crucial for our everyday-life. Coal accounts for a great deal of this electricity. The following paragraphs contain a short overview on what coal actually is, how much of it exists worldwide and where it is found. The main focus of this chapter will be on the individual technologies available to convert coal into electricity; these will then be used to analyse the diffusion of innovations. Furthermore, a brief outlook on the market for power 
plant technology is given. At the end of this chapter the past, present and particularly the future role of coal in electricity production will be covered.

Coal is a collective term for a variety of solid fossil fuels and refers to several combustible materials comprising a continuous scale of calorific value. Often this range of different materials is divided into four sub-categories: (1) Anthracite, (2) bituminous coal, (3) subbituminous coal, and (4) lignite (often also called brown coal). ${ }^{2}$ The categorisation used in this paper will be even more aggregated and refers to the international coal classification of the Economic Commission for Europe (UN/ECE). This classification recognises two categories of coal:

- hard coal - Coal of gross calorific value greater than $5700 \mathrm{kcal} / \mathrm{kg}(23.9 \mathrm{GJ} / \mathrm{t})$ on an ashfree but moist basis and with a mean random reflectance of vitrinite of at least 0.6

- brown coal - Coal with a gross calorific value less than $5700 \mathrm{kcal} / \mathrm{kg}(23.9 \mathrm{GJ} / \mathrm{t})$ containing more than $31 \%$ volatile mater on a dry mineral matter free basis.

This division into two categories includes anthracite and bituminous coal in hard coal and sub-bituminous coal and lignite/brown coal (and peat) in brown coal. Due to the fact that coal quality varies from deposit to deposit and especially from country to country the UN/ECE classification is not true for all nations. For some countries sub-bituminous coal is categorised as hard coal while in most countries it is included in brown coal. ${ }^{3}$

At the end of 2005, according to the WEC (2007), 847 giga tons of proved recoverable coal reserves existed worldwide. Table 1 covers the allocation of coal reserves from a national point of view, whereby the unequal distribution of coal across the world becomes even more apparent. The three countries with the largest coal reserves represent roughly $60 \%$ of the world's proved recoverable reserves. The USA alone accounts for $29 \%$, which are equal to 242 GT, whereas Germany ranks thirteenth in the list.

\subsection{Power plant technology}

Power plant technology has seen major improvements in efficiency and decrease in emissions throughout its history. However, power stations are complex technical constructions consisting of countless parts and therefore requiring various branches of scientific knowledge such as material research or aircraft construction. Changes to existing technologies are often

\footnotetext{
${ }^{2}$ Peat is sometimes included in lignite/brown coal, but in part also categorised separately (e.g. old World Energy Council reports). Some countries even tend to categorise peat as a renewable energy source for the time span which it needs to form peat is relatively short compared to other fossil fuels.

${ }^{3}$ The IEA includes sub-bituminous coal in hard coal for Australia, Belgium, Finland, France, Iceland, Japan, Korea, New Zealand, Mexico, Portugal and the United States. This thesis will follow IEA practice.
} 
merely incremental and even then require a long time to be implemented. Main electricity power stations are running up to 35-45 years or even longer and represent major investments. ${ }^{4}$ Once a power plant is build it represents sunk costs and hardly any changes to its basic specifications can be made. This is why innovations in coal-fired power plants take time to diffuse.

Table 1: Proved coal reserves of the top fifteen countries in 2005 [million tons]

\begin{tabular}{l|rrrr}
\hline & Hard coal & $\begin{array}{c}\text { Brown } \\
\text { coal }\end{array}$ & TOTAL & $\begin{array}{c}\text { Share of } \\
\text { total }\end{array}$ \\
\hline United States of & & & & \\
America & 212347 & 30374 & 242721 & 0.29 \\
Russian Federation & 49088 & 107922 & 157010 & 0.19 \\
China & 62200 & 52300 & 114500 & 0.14 \\
Australia & 39200 & 37400 & 76600 & 0.09 \\
India & 52240 & 4258 & 56498 & 0.07 \\
South Africa & 48000 & 0 & 48000 & 0.06 \\
Ukraine & 15351 & 18522 & 33873 & 0.04 \\
Kazakhstan & 28170 & 3130 & 31300 & 0.04 \\
Serbia & 6 & 13879 & 13885 & 0.02 \\
Poland & 6012 & 1490 & 7502 & 0.01 \\
Brazil & 0 & 7068 & 7068 & 0.01 \\
Colombia & 6578 & 381 & 6959 & 0.01 \\
Germany & 152 & 6556 & 6708 & 0.01 \\
Canada & 3471 & 3107 & 6578 & 0.01 \\
Czech Republic & 1673 & 2828 & 4501 & 0.01 \\
\hline Top 15 & 524488 & 289215 & 813703 & 0.96 \\
All others & 9234 & 24551 & 33785 & 0,04 \\
\hline TOTAL WORLD & 53722 & 313766 & $\mathbf{8 4 7 4 8 8}$ & $\mathbf{1 0 0}$ \\
\hline Source: WEC & & & & \\
\hline & & & & \\
\hline
\end{tabular}

Source : WEC (2007)

As Figure 2 shows, several different coal technologies are currently in practice or subject to intense research activity. The most important technological trajectory is however the

\footnotetext{
${ }^{4}$ A conventional hard coal power plant of $500 \mathrm{MW}_{\mathrm{e}}$ will cost approximately $€ 550$ mill (Vattenfall 2006).
} 
pulverised coal-fired steam cycle (PC) which is the basis for all other coal combustion technologies. Modern PC technology is well developed and accounts for over $90 \%$ of coalfired capacity worldwide (WCI 2005). Therefore it will be taken as a reference technology for this paper.

The earliest conventional coal-fired plants used lump coal which was burnt on a grate in boilers to raise steam. Nowadays, the coal is first milled to fine powder in order to increase the surface area and to make it burn more quickly. The powdered coal is blown into the combustion chamber of a boiler where it is burned at temperatures of $1300-1700^{\circ} \mathrm{C}$. The relieved heat energy converts water - flowing through tubes lining the boiler - into steam. This high pressure steam is passed into a turbine where heat energy is partly transformed into mechanical energy. This mechanical energy in turn drives a generator converting mechanical energy into electricity. The steam passing the turbine is returned to the boiler to be reheated.

\section{Figure 2: Classification of technologies for modern coal-fired power plants}

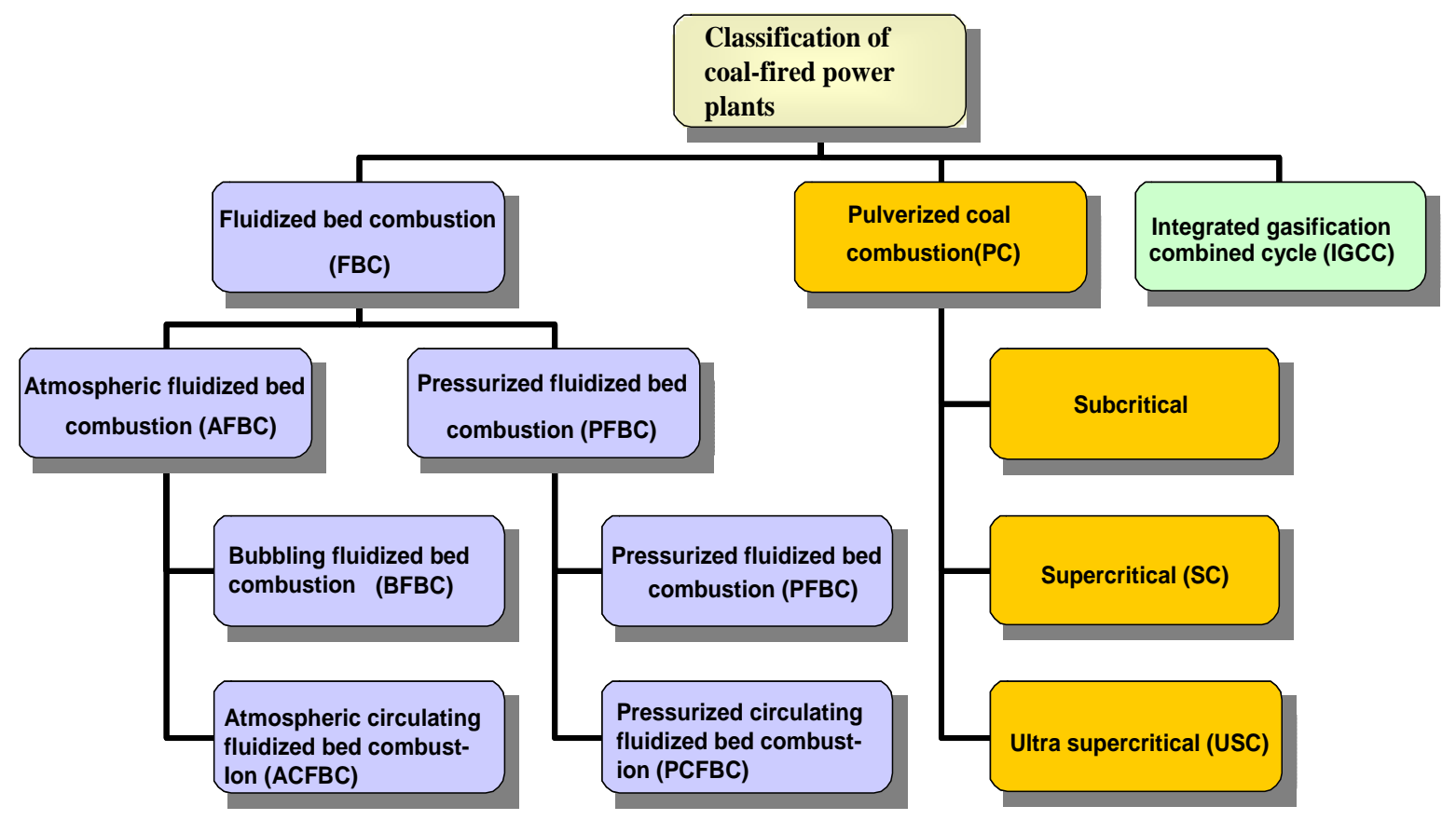

\subsubsection{Pulverised coal-fired steam-cycle}

As Table 2 shows, the steam condition when entering the turbine decides if a PC plant is called subcritical, supercritical or ultra supercritical. Steam is called supercritical when it exceeds the critical point. ${ }^{5}$ The higher the temperature and pressure of the steam is, the higher

\footnotetext{
${ }^{5}$ Critical point describes the temperature and pressure above which the working fluid - in this case water - no longer turns into steam but instead decreases in density when it is heated above 'boiling point'. By eliminating
} 
the efficiency of the power plant. ${ }^{6}$ The three specific PC technologies are explained below.

\subsubsection{Subcritical}

Subcritical power plants represent the most inefficient types of coal-fired power plants, yet the majority of all power station capacity. Temperatures and steam pressure are below $374^{\circ} \mathrm{C}$ and 221.2 bars. Steam passing the turbine is usually not reheated but exhausted into the atmosphere. Modern subcritical power stations achieve efficiency degrees of approximately $38 \%$. Because subcritical power plants are the most common technology worldwide this paper will choose subcritical power stations as base technology. The diffusion of other technologies will be compared to the existence of sub-critical power stations.

Table 2: Classification of PC power plant technologies (efficiencies for steam coal)

\begin{tabular}{|l|r|r|r|r|}
\hline Category & Unit & Subcritical & Supercritical & $\begin{array}{c}\text { Ultra Super- } \\
\text { critical }\end{array}$ \\
\hline Year & & $<\mathbf{1 9 9 0}$ & $\mathbf{1 9 9 0}$ & $>\mathbf{2 0 0 0}$ \\
\hline Live Steam Pressure & {$[\mathrm{b} a r]$} & $165-221.2$ & $221.2-250$ & $>250$ \\
Live Steam & {$[\mathrm{C}]$} & $<540$ & $540-570$ & $>570$ \\
Temperature & & & & \\
Reheat Steam & {$[\mathrm{C}]$} & No reheat & 560 & $>580$ \\
Temperature & & No & Yes & Yes \\
Single Reheat & & No & No & Yes \\
Double Reheat & {$[\%]$} & $\sim 38$ & $\leq 43$ & $\geq 44$ \\
Generating Efficiency & & & & \\
\hline
\end{tabular}

Source: Lako (2004)

\subsubsection{Supercritical (SC)}

The first generating units with supercritical steam conditions were constructed in the 1950s in the USA. Increased temperatures and pressures also required newly developed, very resistant types of steel, which material research had not yet been able to provide. Fatigue fractures caused interruptions in operation, making supercritical power stations noncompetitive at that time. It was not until twenty years later that material was available which allowed working with supercritical steam conditions. Modern supercritical power stations work with steam

the transition into steam (phase change) the efficiency of the process can be improved. For water the actual conditions are temperatures and pressures of over $374^{\circ} \mathrm{C}$ and 221.2 bar respectively.

${ }^{6}$ The rule of thumb in power plant construction is that each additional bar causes a $0.005 \%$ increase in degree of 
pressures between 221.2 - 250 bar and temperatures between $540-570^{\circ} \mathrm{C}$. Steam is reheated after passing the turbine, such power stations thus achieve degrees of efficiency of as much as $43 \%{ }^{7}$

This paper will analyse the diffusion of supercritical power plants as an innovation compared to the older subcritical stations.

\subsubsection{Ultra supercritical (USC)}

During the 1990s, material research made rapid strides towards steel types that were even more resistant to heat and pressure than the ones used for supercritical power stations. This enabled plant constructors to work with temperatures well above $600^{\circ} \mathrm{C}$ and pressures above 300 bars. Since the construction of the first ultra supercritical power station approximately 60 generating units have been built, are under construction or are currently planned. Most of these units have been constructed around the year 2000 and operate as demonstration projects. The degrees of efficiency of ultra supercritical power plants still vary significantly. The least efficient plant is located in Japan (Matsuura EDP 1) and achieves 40.5\%, whereas the most efficient unit is the German plant Niederaussem $(\mathrm{K})$ with a degree of efficiency of $45 \%$. Nevertheless, power plants with efficiencies above $47 \%$ are already planned. USC technology will not be analysed in the paper since it is still in a very early innovation phase, thus an ex post analysis of technology diffusion is not yet possible.

\subsubsection{Other technologies}

Another technology is the Integrated coal gasification combined cycle (IGCC). IGCC is relatively new to power generation. The first plant - located in the USA - was commissioned in 1984 (Coolwater Plant). In IGCC power plants coal is gasified substoichiometrically ${ }^{8}$ at temperatures of $1700^{\circ} \mathrm{C}$ in a gasifier within the plant; this is why the term "integrated gasification" is used. The resulting synthetic gas - called syngas (or fuel gas) - consists mainly of molecular hydrogen $\left(\mathrm{H}_{2}\right)$ and carbon monoxide $(\mathrm{CO})$. After leaving the gasifier the syngas is cooled down and subsequently cleaned. The syngas is then burned in a gas turbine, whereas the waste heat is in turn used to convert water into steam in a secondary loop. The steam is fed into a steam turbine, which also drives a generator. The combination of gas turbine and steam turbine is called combined cycle. Today, 16 IGCC generating units exist worldwide; one in Germany (Schwarze Pumpe). All of them are demonstration projects. Due to the very early diffusion phase we do not look at IPPC technologies in this paper.

\footnotetext{
efficiency and each additional degree Celsius causes a $0.011 \%$ increase.

7 The world's most efficient supercritical power currently operating is the KNG owned power station Rostock I, which achieves a degree of efficiency of 43\% (IEA 2007a).
} 
A third potential technology to analyse within this paper would be the "fluidised bed combustion" (FBC). FBC relates to the combustion process, which takes place in a layer (bed) of sand-like material suspended (fluidised) within a column. The bed is streamed by upwardblowing jets of air during the combustion process. This results in a turbulent mixing of gas and solids. FBC boilers operate at temperatures of approximately $800-900^{\circ} \mathrm{C}$, which is relatively low compared to other combustion processes such as those in IGCC and supercritical PC. FBC was developed because of the ambition to find an alternative for endof-pipe solutions of flue gas cleaning technologies. FBC substantially reduces the amount of $\mathrm{SO}_{\mathrm{x}}$ emissions and is therefore also regarded as clean coal technology.

Atmospheric fluidised bed combustion is a widespread technology with approximately 300 units installed worldwide. AFBC uses a simple steam cycle operating at subcritical conditions. AFBC is divided into bubbling fluidised bed combustion plants (BFBC) and circulating fluidised bed combustion (CFBC). BFBC shows only an efficiency of approximately $30 \%$ and is used for small units up to $30 \mathrm{MW}_{\mathrm{e}}$. $\mathrm{CFBC}$ on the other hand achieves efficiencies of 38$40 \%$ and plants with as much as $600 \mathrm{MW}_{\mathrm{e}}$ are designed.

Pressurised fluidised bed combustion is comparatively new to power plant technology and uses a combined cycle to generate electricity. It is also split up into two modes: pressurised fluidised bed combustion (PFBC), and pressurised circulating fluidised bed combustion (PCFBC). Plants build in the 1990s achieve efficiencies of as much as $42 \%$. However, this technology still exists only in connection with demonstration projects with very small capacity (up to $80 \mathrm{MW}_{\mathrm{e}}$ ). Nevertheless, PFBC is expected to reach degrees of over $45 \%$ (IEA/OECD 2007).

AFBC and PFCB plants are not predicted to gain much importance for main electricity production in the near future. Due to the small capacity of units and comparatively low efficiencies the technology is not interesting for utilities. Since AFBC and PFBC work well with other solid fuels, especially waste, these technologies are of more relevance for industrial and commercial operators (Prognos 2007, p.62). Therefore, this paper will not consider fluidised bed combustion technology in the further analysis.

\subsection{The market for power plant technology}

Coal has a long tradition as an energy source. It was not until the 1960s that oil replaced coal as the world's largest source of primary energy. Nevertheless, coal has remained the greatest source for electricity production across the world. In 2005, coal accounted for approximately

\footnotetext{
${ }^{8}$ Substoichiometric: under controlled shortage of air/oxygen.
} 
$40 \%$ of all electricity produced worldwide, which is twice as much as gas being the second largest source of electricity generation. Figure 3 shows the development within the electricity generation sector concerning inputs since 1971. Throughout the general increase in electricity production from 18.9 EJ in 1971 up to $65.9 \mathrm{EJ}$ in 2005 , coal has maintained a stable share in worldwide electricity production of approximately $40 \%$. In 2005 , consumption of steam and brown coal for electricity production added up to 2487 Mtoe/a representing a $79.8 \%$ rise since 1985 (IEA 2007b).

\section{Figure 3: Share of single energy sources in worldwide electricity output}

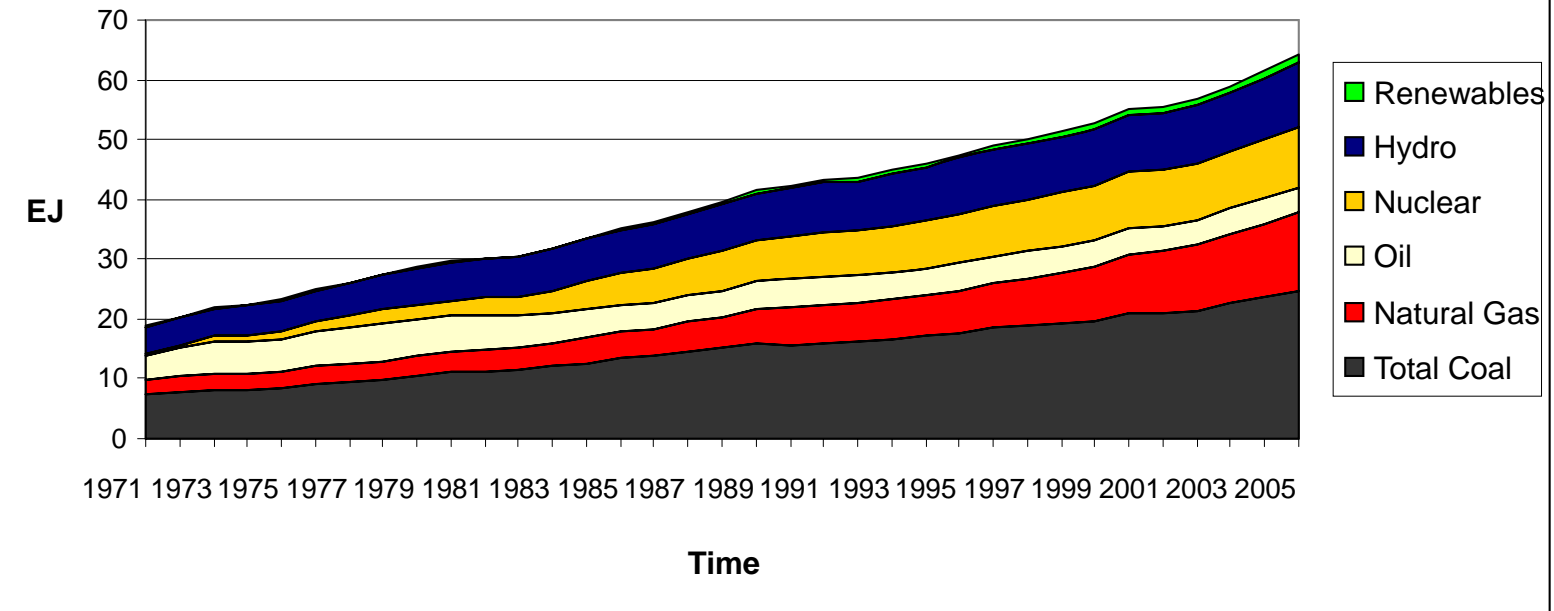

Source: IEA $2007 b$.

This rapidly increasing demand has been satisfied mostly by domestic production. In 2005, only $14.6 \%$ of steam and brown coal production was destined for international trade. ${ }^{9}$ The top five producers in 2005 were China, the USA, India, South Africa and Australia, accounting for $77.4 \%$ of steam and brown coal production.

The value of the market for power plant equipment is economically quite significant. The ordering value for turbines only was $\$ 40$ bn in 1998 and has constantly increased ever since. The total value of the complete market is by far greater than $\$ 40 \mathrm{bn}$. This becomes evident when knowing that by now many companies gain much of their profits with power plant services such as monitoring and diagnostic services. For instance, Alstom (power sector) already derives $36 \%$ ( $\$ 3.198 \mathrm{bn})$ of their profits from the power plant service business (Alstom 2007). The market for power generating technology is destined to grow substantially over the next decades. Growing energy demand and thus increasing demand for power plant

\footnotetext{
${ }^{9}$ International trade in brown coal is negligibly small for the calorific value of lignite and sub-bituminous coal
} 
equipment will be followed by enormous investments. According to the IEA, expenditures in the power generating sector will cumulate to $\$ 11.3$ trillion in the period of 2004-2030. Projects in the transmission and distribution sector account for $54 \%$ or $\$ 6.1$ trillion. Capital investments for expanding supply capacity and replacing existing plants account for the remaining $46 \%$ or 5.2 trillion. This results in an average annual ordering value of \$208 billion for power plant equipment (IEA 2006). These figures point out the significance of the power plant technology sector and the relevance of analysing it.

\section{Innovation and diffusion of innovations - the lead market concept}

This section intends to answer three questions: First, what is a lead market and how do these markets push the diffusion of innovations? Second, what constitutes a lead market? Third, what are nation-specific characteristics of lead markets?

\subsection{Definition of lead markets}

The lead market hypothesis suggests that among different innovation designs competing in international markets there is one that supersedes other nation-specific designs in other countries and therefore, eventually, diffuses globally. Moreover, the lead market hypothesis assumes that certain demand and market conditions in a country are responsible for whether this country adopts the internationally diffusing design or not. An innovation design is defined as a "...specification or configuration of an innovation idea" (Beise 2001, p. 9). Thus one innovation can result in several different designs. As market contexts vary among countries, different designs of the same innovation idea emerge, having the same function but different modes of specification. ${ }^{10}$ Economically speaking, different designs are characterised by high substitution elasticity in consumption. All of these innovation designs compete in the global market and frequently one of them becomes dominant worldwide. IBM's PCs, for instance, have become the dominant design for home computers as Commodore, Atari and Apple computers failed to succeed in the global market. A dominant design is thus defined as a design that is adopted by a majority of users (Utterback 1994, p.24).

The term "lead market" still appears in the literature with varying meanings; in part discussed from a demand-side perspective and in part from a technological viewpoint. The demand-side perspective follows Nelson's view that "social need, usually manifesting itself through perceived opportunities for private profit, not chance, is the cause of interventions. When the time is ripe, they are inevitable" (Nelson, 1959, p. 29). Beise (2001, p. 8) identifies three main

\footnotetext{
does not allow trade in economic terms.

${ }^{10}$ Apple and IBM computers, for instance, fulfil the same function but differ in design and other modes of specification.
} 
groups of definitions found in the literature. According to these groups a lead market is (1) the country where an innovation is invented ${ }^{11},(2)$ the country where a subsidiary belonging to a multinational firm starts a marketing campaign which later becomes dominant within the entire company, ${ }^{12}$ and (3) the country which first widely adopts and accepts an innovation. ${ }^{13}$ In this paper only the last definition will be used. The reason for not following the first definition is because it applies only to a limited amount of innovations. Many innovations were first widely adopted in countries where the innovation had not been initially introduced. Following the first definition, a country would be called lead market although the economic exploitation and diffusion of the innovation takes place in another country, which leaves the inventing country in everything but a leading position. Thus the definition of a lead market used in this paper does not depend on the regional origin of the invention. The second definition of lead markets also has to be discarded in this paper, since it describes a marketing strategy and is not helpful in understanding the role of lead markets for technical innovation designs on a national level.

To conclude, lead markets are markets which adopt an innovation design before it is adopted by most other countries and therefore lead the global diffusion of the innovation.

In order to set the stage for a discussion on the characteristics of lead markets it is useful to look at the process of market acceptance or market diffusion of an innovation. Every innovation design that will eventually become globally successful requires some time to reach market saturation. First, there is the introduction phase in which only a small share of the market adopts the innovation design and in which it is not clear to market participants whether the design is a success or a failure. A successful innovation design reaches a take-off point where sales increase dramatically and the number of adopters grows rapidly. How long it takes for an innovation design to reach take-off point after being introduced to the market varies, but usually the time span covers several years (Tellis, Stremersch and Yin 2003; Gort and Klepper 1982). Most diffusion curves follow an S-shaped curve as shown in Figure $4 .{ }^{14}$ The diffusion of the dominant innovation design in the lead market is followed by the diffusion in other countries with a more or less distinct time lag. The countries following the lead market will be called lag markets henceforth. Beise-Zee and Rammer (2005) emphasise that in reality the curves often show different shapes indeed but the general characteristics of

\footnotetext{
${ }^{11}$ Innovations concerning a certain technology take place in only one or a few countries, which are among the lead countries for this technology; the country where the innovation was first developed is the lead market. See Yip (1992, p. 43).

${ }^{12}$ Bartlett and Goshal (1986) use this understanding of lead markets being an organisational concept of global marketing.

${ }^{13}$ For examples see Seydel and Wietschel (2005, p.5) or Beise-Zee and Rammer (2005).
} 
the curves remain.

Figure 4 shows the international diffusion of a globally dominant design. Before the dominant design succeeded in the lead market it competed with other innovation designs on a national and a global level. These other designs did not fit the global trend and failed sooner or later.

\section{Figure 4: An international diffusion pattern of an innovation design}

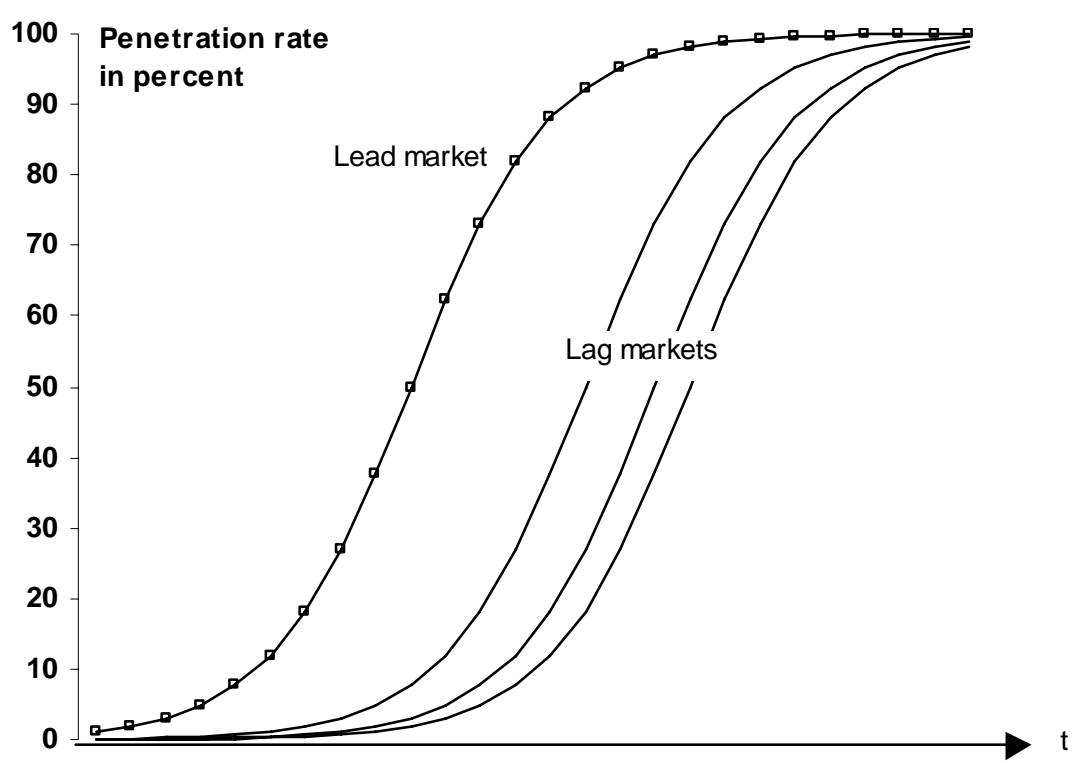

Source: Beise (2001)

Figure 5 shows the connection between the competing innovation designs. The lag market switches from the inferior design A to the innovation design B, which succeeded in the lead market, and thus consequently continues to push the global diffusion of design B.

The global dominant design does not necessarily have to be adopted in every country. It is possible that the demand in one country is idiosyncratic and not anticipatory. Demand is idiosyncratic if the users in this specific country prefer innovation designs that are not demanded in other countries. ${ }^{15}$

This understanding of the term lead market is closely connected to the work of Michael E. Porter on the competitive advantage of nations (Porter 1990) and the studies of Bartlett and Ghoshal (1990). They use the term lead markets in the context of the ability of markets to stimulate global innovations. Lead markets are "the markets that provide the stimuli for most global products and processes of a multinational company“(Bartlett and Ghoshal 1990, p.

\footnotetext{
${ }^{14}$ For the various mathematical specifications of diffusion curves see Mahajan et al. (1990).

${ }^{15}$ Markets can be idiosyncratic for several reasons; e.g. cultural, climatic or geographical reasons. For instance, German demands for domestic folk music is idiosyncratic, since other countries are very unlikely to also adopt this music.
} 
243). According to them, lead markets occur because "local innovations in such markets become useful elsewhere as the environmental characteristics that stimulated such innovations diffuse to other locations“ (Bartlett and Ghoshal 1990, p. 243). Possible environmental characteristics may be: political framework or demand preferences. This understanding of the term lead market is borrowed by Beise (2001) and complemented by the following clarifications, which will be also used in this paper:

\section{Figure 5: An international diffusion pattern of competing innovation designs}

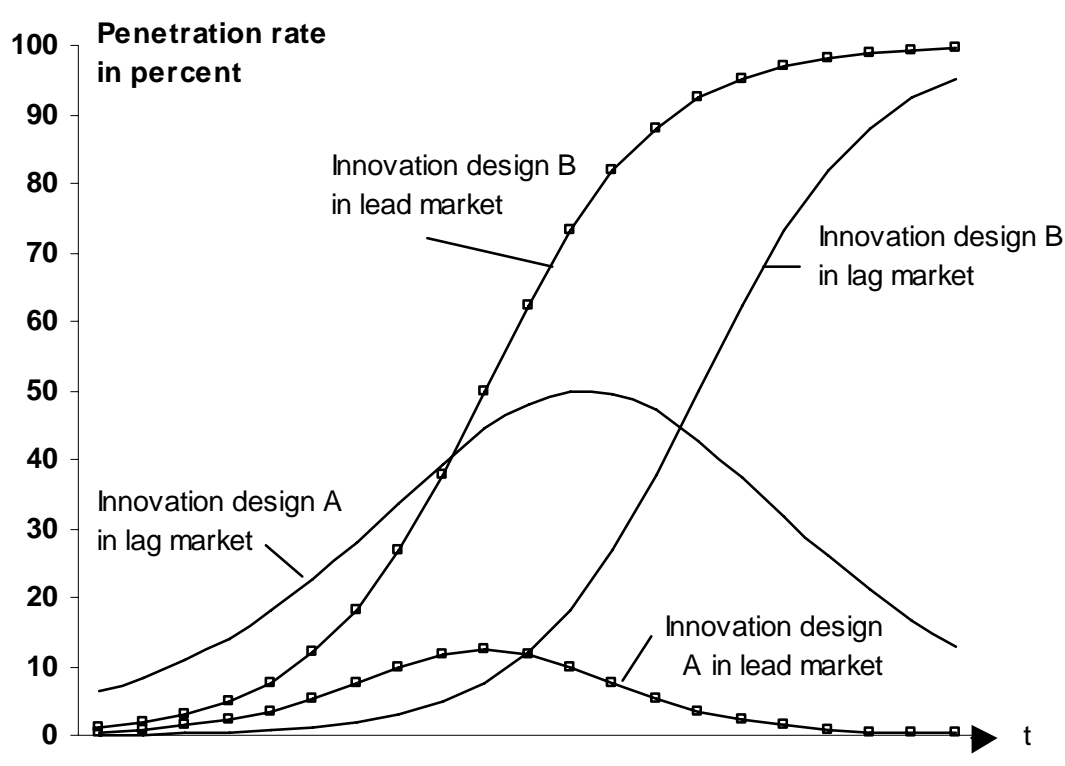

Source: Beise (2001)

(1) Nations can be said to have "adopted an innovation" when the innovation has reached the take-off phase of diffusion.

(2) The regional origin of an innovation does not matter for the definition of lead markets. ${ }^{16}$

(3) Lead markets do not have to be the most "innovative" markets but the countries that first adopt innovation designs before they become globally dominant. Beise describes these countries, following Porter (1990), as anticipatory markets. An example of an anticipatory market is shown in Figure 5. The lead market comes up with design B later than the more "innovative" lag market with design A, but adopts the dominant design B before the lag market does so. Anticipatory does not mean that the lead market is able to forecast that users in other countries will have the same needs in the future. Demand can be called anticipatory, as Beise suggests, when it occurs earlier than in other countries.

(4) Lead markets are product- or process-specific. That means that the lead market for one

\footnotetext{
${ }^{16}$ However, Beise (2004) states that many innovations are developed in response to local demand. This is why
} 
product can be a different country than the lead market for another innovation.

(5) No assumption is made stating that a lead market exists for each innovation, although it might become internationally successful.

\subsection{Lead Market factors}

In the literature, several different approaches are used to explore the question of why some nations adopt certain innovations faster and more broadly than others. These factors may be interpreted as a "selectional environment" in the sense of Nelson and Winter (1977), however they do not only explain why a technology is selected but also why it is selected in a specific country. Beise (2001) and Beise and Rennings (2005) have identified a typology of six basic groups of advantages in a lead market, these being

- price advantage,

- demand advantage,

- transfer advantage,

- export advantage,

- market structure advantage and

- regulation advantage.

A price advantage arises from national conditions that result either in relative reductions in the price of a nationally preferred innovation design compared with designs preferred in other countries or in anticipation of international factor price changes. Countries can gain a price advantage if the relative price of the preferred national innovation design decreases, and if the price advantage compensates for differences in demand preference with regard to foreign countries. The price mechanism is the core of the globalisation hypothesis (Levitt 1983), according to which consumers in foreign markets "capitulate" to the attraction of lower prices and abandon their initial endowment of goods. Price reductions are mainly due to cost reductions based on static and dynamic economies of scale (learning-by-doing). Market size and growth are examples of country-specific factors creating economies of scale. Another price advantage emerges from anticipatory factor prices in the lead market. Factor price changes can induce innovation. If the new relative prices occur worldwide, the same innovations are adopted worldwide as well.

Demand advantages originate from national conditions which result in anticipating the 
benefits of an innovation design emerging at a global level. A good example is provided by off-grid solutions in the energy and telecommunication sector. Such innovations are more beneficial for industrialised, geographically large countries with a low population density, such as Scandinavia, and are thus more likely to be adopted first in such countries. When other countries catch up, they demand the same innovation that has already been introduced in the country at the forefront of the trend. Another example is provided by trends related to environmental problems such as climate change. Some countries are more exposed to the risks of rising temperatures (e.g. countries with above-average risks of flooding such as the Netherlands) than others and will thus anticipate these trends earlier.

Transfer advantages are national conditions that increase the perceived benefit of a nationally preferred innovation design for users in other countries or by which national demand conditions are actively transferred abroad. The perceived benefit increases when information on the usability of the innovation design is made available. The initial adoption of an innovation of unknown merit reduces the uncertainty and therefore the risk for subsequent adopters and kicks off a bandwagon effect - also referred to as the demonstration effect of adoption (Mansfield, 1968).

Conditions which promote the inclusion of foreign demand preferences in nationally preferred innovation designs constitute a national export advantage. Three national export advantage factors can be identified: domestic demand that is sensitive to the problems and needs of foreign countries, the established export experience of national firms, and the similarity of local market conditions to foreign market conditions. Dekimpe et al. (1998) support the hypothesis already proposed by Vernon (1979) that the greater the cultural, social and economic similarities are between two countries, the greater is the likelihood that an innovation design adopted by one of the two countries will be adopted by the other country as well.

The market structure effect focuses mainly on the degree of competition. Competition and entrepreneurial effort have been described by researchers such as Posner (1961) and Dosi et al. (1990) as two of the main determinants of international patterns of innovation. The lead market is usually highly competitive. This is due to the fact that faster development and more market-oriented innovations are supported by competitive market structures. Firstly, companies engaged in fierce competition will demand more innovations from suppliers because they are able to reap greater competitive rewards from using innovative parts than monopolies. (Porter 1990). Secondly, competing firms are under more pressure to follow the 
example of firms which have already adopted a new technology (Mansfield 1968). Thirdly, and possibly most importantly, more innovation designs are tested in a competitive market than in a monopoly market.

A country has a regulation advantage if the legal framework allows companies to plan on a mid- and long-term scale and at the same time exerts pressure on firms to come up with innovative ideas (Beise and Rennings, 2005). Every consumer and every company is subject to national and international regulative boundaries. These frameworks determine how companies align their strategies and they are the basis for decision-making processes on a mid- and long-term scale. This especially applies to power suppliers, be they private or governmental. Long amortisation durations and extraordinary high investment costs make it necessary to have a stable or at least predictable legal frame. Without it, the risk and uncertainty of investing results in postponed renewal of power plant fleets. This is an unacceptable state for economies claiming to be a lead market.

Consequently, we find six lead market factors examined in this thesis (see Figure 6). How much exactly each factor contributes to the lead market potential is unknown, and may differ from case to case. The following sections aim to find answers to this question with regard to power plant technology.

Figure 6: National lead market factors

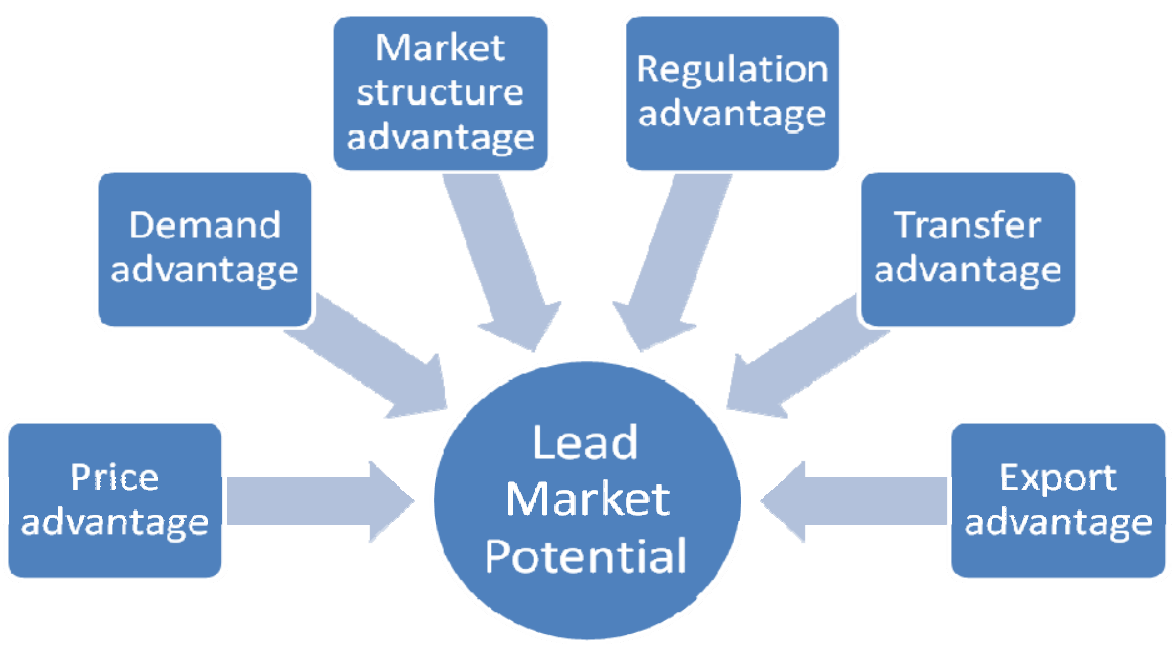

\section{The case of coal power plant technologies}

After presenting background information on coal in section 2 and introducing the lead market 
concept in section 3, these theoretical foundations will now be applied to innovations of coalfired power plant technology. The section covers the diffusion of pulverised coal-fired steam cycle plants which have been introduced and selected in section 2 .

\subsection{Supercritical power plants}

Supercritical power plants have been used for several decades and allow the creation of diffusion curves for the United States, Germany, Japan and China. Figure 7 shows the diffusion over time as a share of supercritical power plants in the entire capacity of coal-fired power plants installed. The data were retrieved from the UDI World Electric Power Plants Database (WEPP 2007).

Figure 7: Diffusion of supercritical coal-fired power plants in selected countries

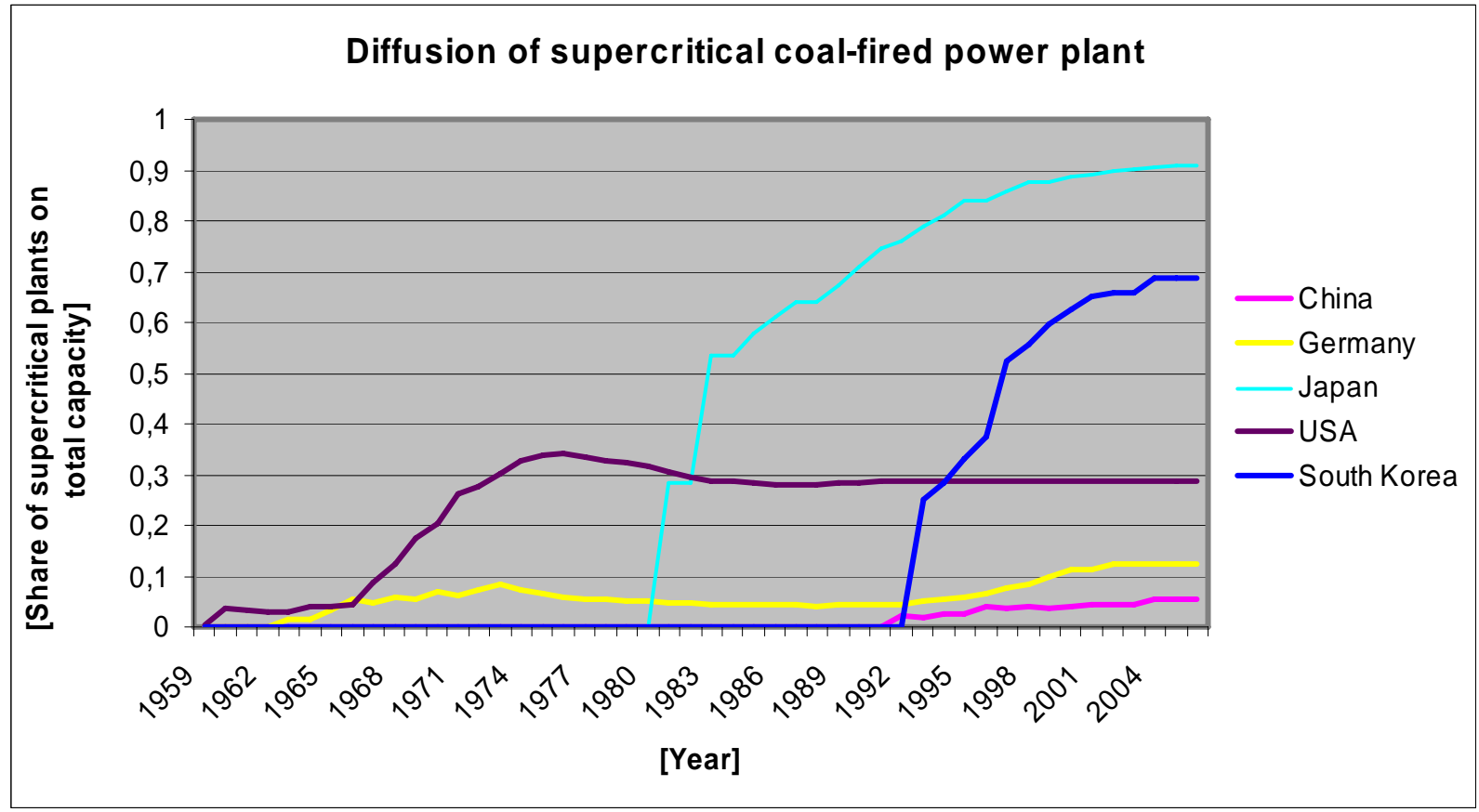

Source: ZEW 2007 according to WEPP 2007.

\subsubsection{USA}

The first supercritical coal-fired power plants worldwide were brought to use in the USA. In 1959 the power unit Avon Lake 8 was commissioned and in 1960 four more supercritical power units followed. Material problems with the steel, which could not completely resist the high vapour pressures, delayed the break through of supercritical plants in the early 1960s. In the second half of the 1960s these material problems were overcome and the share of supercritical power plants rose constantly. In 1976, already $34 \%$ of all coal-fired power plants 
operated at supercritical steam condition. The two oil price crises in the 1970 s led to decreasing use of oil in the United States. Nuclear energy and coal-fired plants gained more importance, but unlike what one might have expected, the further diffusion of coal-fired supercritical plants (CFSC) came to a halt in the late 1970s. Moreover, American utilities returned to building more subcritical power plants and the share of supercritical coal-fired power plants decreased. Although the USA has by far the largest capacity of CFSC power units (in 2004: 120 CFSC units) worldwide, circumstances which hindered the total break through of CFSC technology apparently prevailed. On the one hand this may result from relatively low coal prices in the USA, which did not make the building of more efficient power plants necessary. On the other hand it is possible that the United States basically stopped building coal-fired power plants in the late 1970s and early 1980s and that subcritical power plants merely had a longer operating time, which necessarily led to decreasing shares of supercritical plants.

Surprisingly, the United States does not plan to build a single supercritical coal-fired power plant, although this technology first came up in the USA and underwent considerable development in American firms. It is, however, interesting to ask who delivered the supercritical power plants in China, Germany, Japan, South Korea and the USA. As Figures 8 and 9 show for different elements of power plants - turbines in Figure 8 and turbo generating sets in Figure 9 - it appears that American companies still make a profit from supercritical power plants. American firms supplied CFSC power plants in Japan and South Korea. Thereby American companies help to push the global diffusion of CFSC technology and exploit their know-how abroad.

\subsubsection{Germany}

Germany quickly followed the USA in constructing CFSC power units. In 1963 the first supercritical unit "Wedel I" was constructed. Exactly as in the United States, the diffusion of supercritical plants started out promising, but in the mid-1970s, just before reaching a $10 \%$ market share, the diffusion of CFSC power plants stopped and declined again to approximately 4\%. It was not until the reunification of Germany in 1990 that the ratio of supercritical to subcritical power units rose again. Many of the coal-fired power plants that had been operating in the former German Democratic Republic did not meet the environmental requirements of that time. Frequently, this led to a total demolition and reconstruction of the power plant, which was then to employ efficient supercritical units. In 
2004, $12 \%$ of all coal-fired power capacity was supercritical. The German coal sector has received financial support in the form of subsidies and positive legal discrimination. This support and the fact that German utilities could pass on higher costs to the costumer almost without restriction until the liberation of the electricity market in the 1990 s might be an explanation for the sluggish diffusion of efficient coal-fired power plant technology. German companies were besides American companies the first to build CFSC power units. Unlike US firms, however, German power plant suppliers did not manage to compensate for the poor domestic demand by exploiting their technological know-how abroad. Due to Siemens's acquisition of the power generation unit of WEC (Westinghouse Electric Corporation) in 1997 this is about to change. German companies, represented almost entirely by Siemens, are planning to provide plants in Australia and China and Germany is now exporting more CFSC technology than the USA.

\section{Figure 8: Supply and demand for turbines of supercritical power plants}

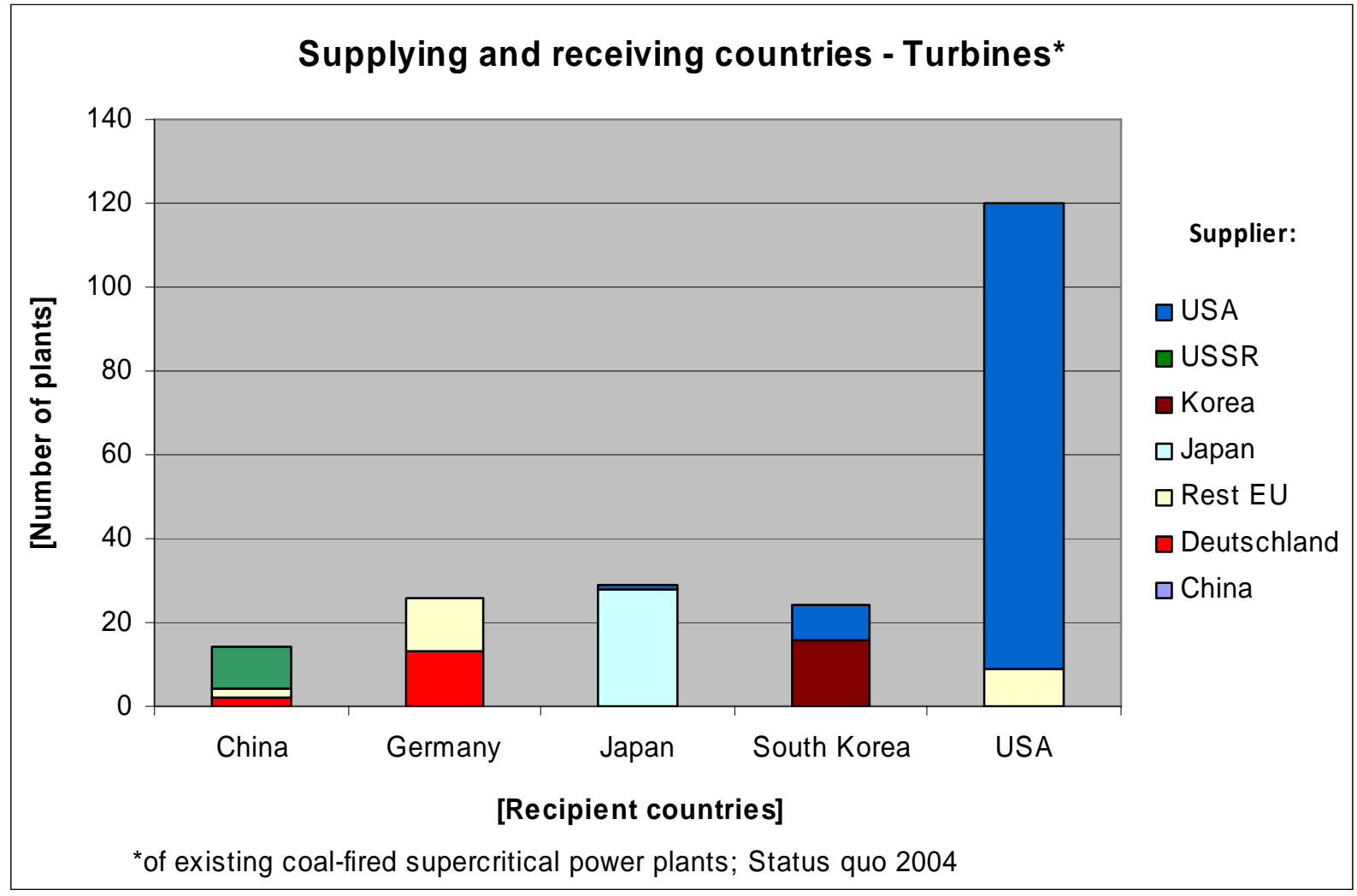

Source: 2007 according to WEPP 2007

\subsubsection{Japan}

The diffusion of CFSC power plants in Japan was clearly influenced by the oil price crisis. 
Before 1971/72, Japan had almost entirely abandoned coal as a fuel for power generation and had built large capacities of oil-fired electricity plants. After the first oil crisis, nuclear energy and natural gas were immediately pushed into the electricity market and - after a short recovery between 1972 and 1978 - Japanese utilities wanted to get rid of their oil-fired plants as quickly as possible. These developments also led to a comeback of coal in the Japanese electricity market. The share of Japanese CFSC power plants quickly rose from $0 \%$ in 1980 to $90 \%$ in 2003 . Two possible reasons for this fast diffusion were probably the permanently high fuel prices in Japan and the fact that Japan did not have such a large installed basis of subcritical power plants as the USA and Germany had. Currently Japan plans to build eleven more CFSC power units - it is thus the second largest receiver of supercritical technology, closely following India. Although Japan built its first CFSC power unit more than twenty years after the United States did, Japanese companies almost entirely managed to provide domestic supply and did not have to fall back on American know-how.

\section{Figure 9: Supplying and receiving countries of turbo generating sets for future} supercritical power plants

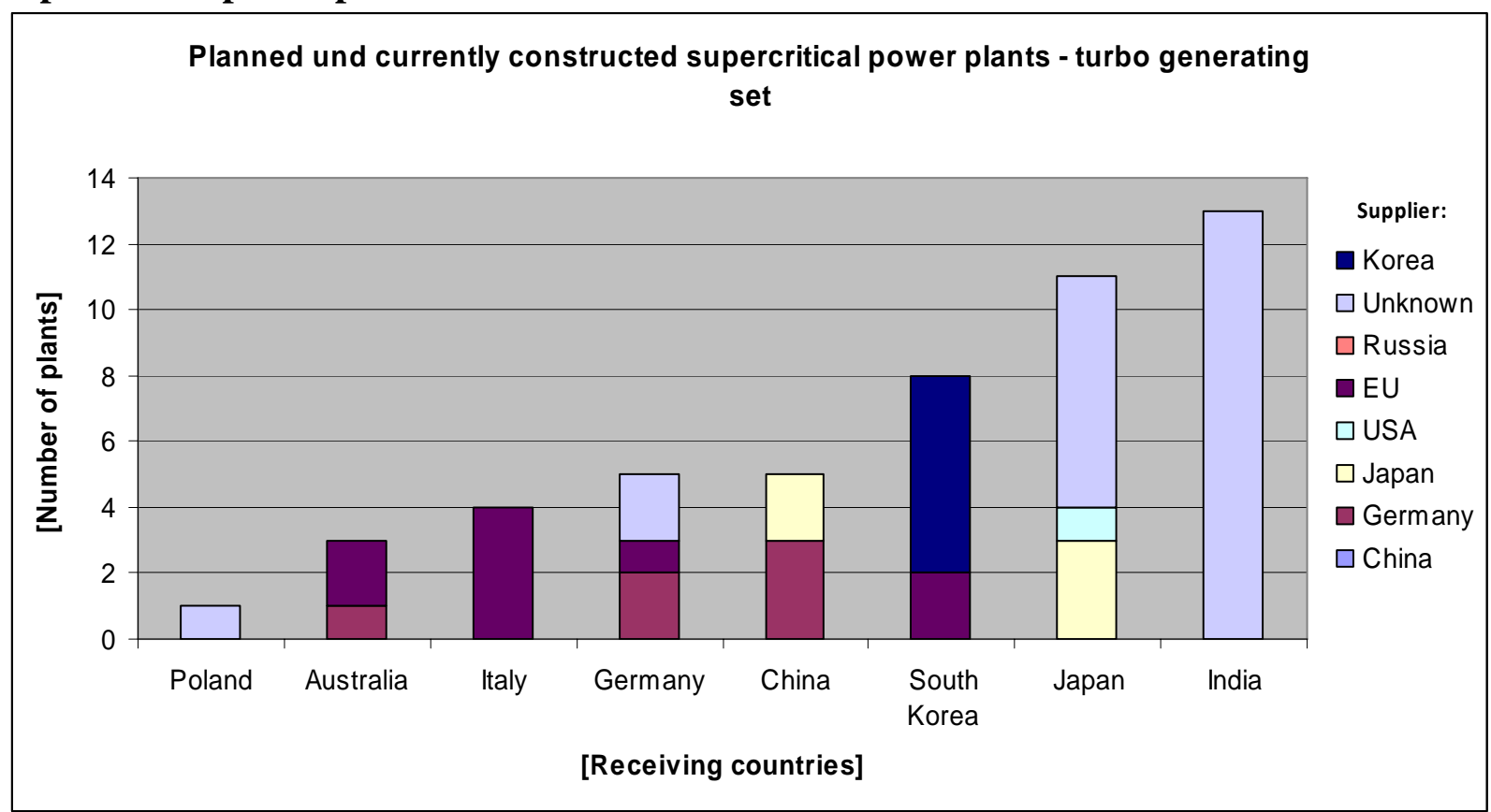

Source: 2007 according to WEPP 2007

For a great share of future Japanese supercritical plants it is unknown who will deliver the technology. However, it is likely that it will mainly be supplied by Japanese companies. This is assumed because in the past over $95 \%$ of all CFSC power plants installed in Japan were supplied by domestic companies. This supports the assumption of Meyer-Krahmer et al. 
(1998) that Japan is characterised by low internationalisation and that Japanese companies are still very much home-base oriented.

\subsubsection{China}

The diffusion of CFSC power plants in China started in 1992. As a result of the continuously increasing Chinese electricity demand, China was not able to cover the demand entirely through domestic production of steam coal. By now, China imports almost as much steam coal as Germany. Consequently, Chinese utilities faced higher fuel prices which might have been an incentive to some utilities to build more efficient power plants. However, the diffusion of supercritical power plants is progressing slowly and the share of CFSC capacity is still below $10 \%$. The major part of Chinese supercritical power plants was supplied by companies located in the Former Soviet Union. We can assume that the wide spread of Soviet power plant technology was motivated by political reasons. This assumption is strengthened by the fact that nowadays suppliers from former Soviet countries have almost completely vanished from the market and future Chinese CFSC power units will be delivered entirely by European companies (mainly Siemens and Alstom). Unlike Japan, China has not managed to deliver one single supercritical power plant through domestic firms. When it comes to CFSC technology, China thus seems to be entirely dependent on foreign companies. However, the diffusion of supercritical power plants in China quickly increases. One reason may be that developing countries such as China and India are currently experiencing a drastic increase in electricity demand. For meeting a power demand developing so fast these countries have to install large amounts of new capacities. Many a times this is evidently accomplished by choosing innovative and efficient technologies. However, this shall not belie the fact that both countries - especially China - are still planning on building large capacities of "inefficient" subcritical coal-fired plants.

Analysing the diffusion curves of CFSC technology shows that the typical lead market pattern as presented in section 3 applies only to a limited extent. In the 1960s and 1970s, the USA seemed to establish a lead market. Diffusion rates are high and large numbers of CFSC units are built. Other countries follow to adopt the American innovation design. When the USA stops building supercritical coal-fired power plants in the late 1970s the picture changes and diffusion curves overlap, which is unusual. Generally, countries that are the first to widely diffuse an innovation design in the domestic market become lead markets. So far, the lead 
market model argues that lead markets do not switch to other countries but are "stable". This has been supported by several empirical analyses regarding, for instance, the diffusion of cellular phones, facsimile machines, diesel motors with direct injection, etc. (see Beise 2001, Beise and Rennings 2005). Here we might see a clear deviation from that rule, since at least the diffusion curves overlap. Japan and Korea surpass Germany and the United States, although they started out as typical lag markets in the early 1980s (Japan) and early 1990s (Korea). Japanese and Korean companies manage to meet their demand almost entirely out of domestic production and American technology plays only a minor role in both countries.

All in all, one central question evolves: Can we determine a lead market for CFSC today? So far this question cannot be definitely answered - there are, however, three optional answers:

- The USA was the first country to diffuse CFSC technology widely and has continually made profits by exporting the technology. Therefore, the USA is the lead market for CFSC technology.

- The lead market for CFSC plants has switched from the United States to Southeast Asian markets - predominantly Japan. This is indicated by overlapping diffusion curves and higher penetration rates of CFSC technology in Japan than in the USA.

- No lead market exists as the lead market model is not robust over long time periods. Long time periods allow many countries such as Japan to eliminate all previous advantages of former leading markets.

Thus, the answer to this question must be postponed since it is necessary to discuss the role of specific lead market factors in more detail first.

\subsection{Ultra supercritical power plants}

Due to the limited diffusion of ultra supercritical power plants to this date, the generation of diffusion curves is not possible. Therefore, the continuous timeline of a general diffusion curve has been split into five discrete time periods; 1950-1990, 1991-1995, 1996-2000, 20012005 and future (=power plants planned or currently under construction).

As Figure 10 shows, the diffusion of coal-fired ultra supercritical (CFUSC) power plants presents a similar picture to what has already been indicated in the analysis of CFSC technology. The first ultra supercritical power plants were constructed in the United States in $1960^{17}$. Exactly as with the first CFSC plants, material problems restricted further diffusion

\footnotetext{
${ }^{17}$ Eddystone I and II; both having a capacity of $353 \mathrm{MW}_{\mathrm{e} .1}$.
} 
in the beginning. However, Eddystone I and II are still in operation. It was not until 1981 that a third CFUSC power unit was constructed; Matsushirna I in Japan. By then, the USA had once again abandoned the technology they had developed. Eddystone I and II were the first and last CFUSC plants installed in the USA and Figure 10 shows that this development is not likely to change in the future. Japan was the major driver for CFUSC technologies during the 1990s. Only Germany, Denmark and the Netherlands kept up with the development and built their own ultra supercritical plants.

Figure 10: Diffusion of ultra supercritical coal-fired power plants

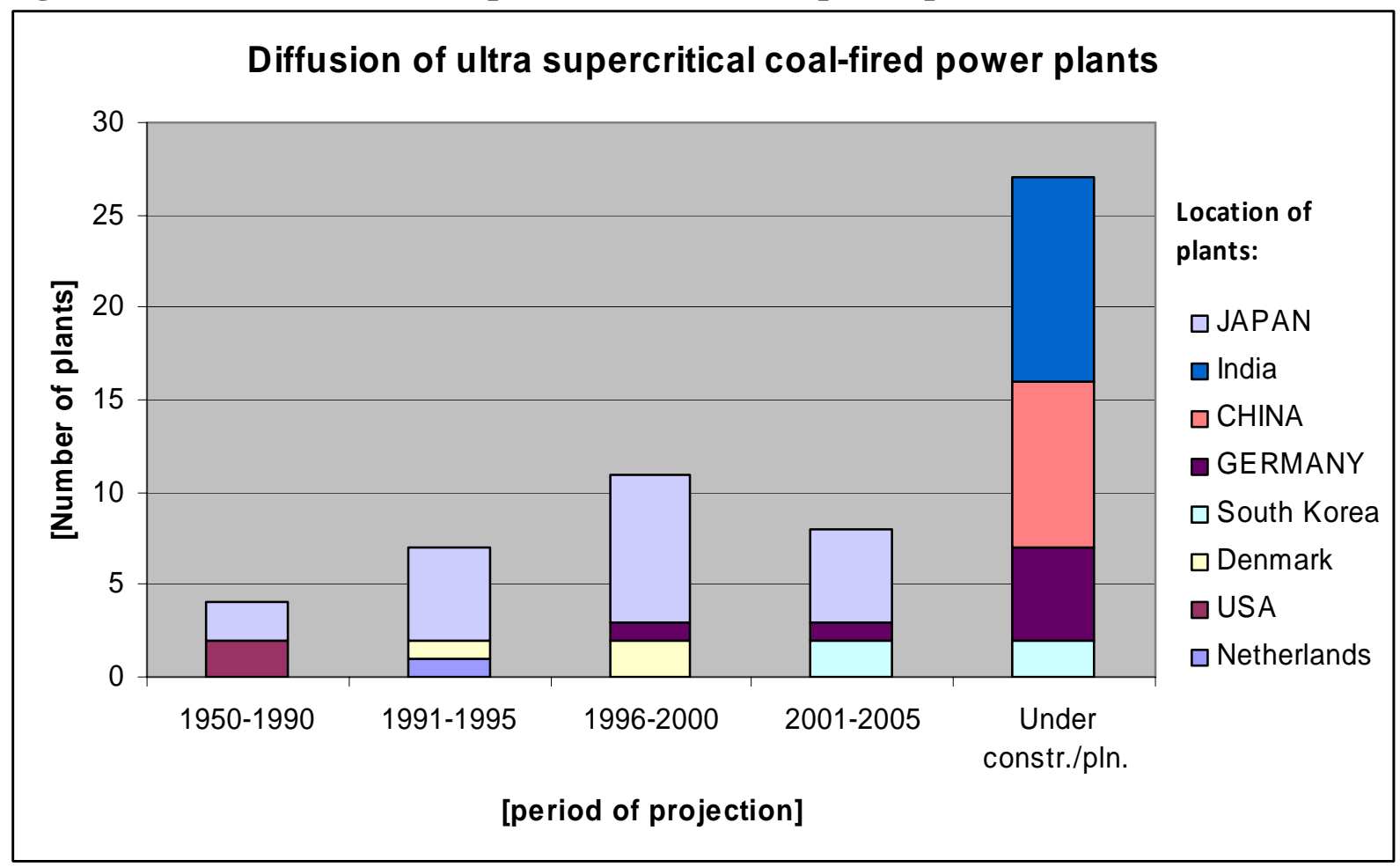

Source: ZEW 2007 according to IEA 2004

For the period before 2005, Japan clearly is the technological leader. This, however, has to be interpreted with care, because CFUSC technology is still very new to the market and so far (Status Quo 2005) only 30 power-generating units worldwide employ the technology. It seems surprising that Japan, which very progressively pushed the diffusion of ultra supercritical power plants before 2005, does not currently plan further construction of USC plants. This does not necessarily have something to do with a renunciation of the technology. Japan has fundamentally renewed its coal-fired power plant fleet since the late 1970s and market penetration rate of supercritical plants is above $90 \%$. It is possible that the market has reached saturation. A look at Germany reveals a different picture - the diffusion of ultra supercritical 
power plants seems about to take off. Maybe this is related to the fact that parts of the installed capacity are decommissioned because they have reached maximum operating time or that the nuclear phase-out in Germany forces utilities to substitute large amounts of capacity with other fuels. The United States complements the impression that has been foreshadowed earlier. Ultra supercritical power plants first appeared in the USA, but just when other countries joined in applying the technology the USA abandoned ultra supercritical coal-fired power plants in the domestic market.

\section{Discussion: The role of lead market factors}

In the following, we will try to explain the adoption of coal-fired power plant technology in the respective countries as stated above by using additional information on the different lead market factors.

\section{Price advantage}

An indicator of a price advantage is the existence of proved fuel reserves in each country, since it can be argued that own reserves guarantee cheap access. Proved reserves are defined by the IEA (2007c, p. I.9) as all resources "that are not only confidently considered to be recoverable but also can be recovered economically, under current market conditions." This means that using proved-reserve data makes it unnecessary to consider national differences in accessibility and extracting costs. There is great inequality concerning the spread of reserves across the globe. According to the World Energy Council (2007), among the four countries under analysis (the USA, China, Japan and Germany), the United States has by far the largest coal reserves at its disposal. China can also rely on huge coal deposits, whereas Germany's and Japan's total hard coal reserves are negligible. Thus the United States has a price advantage caused by abundant coal reserves compared to the other countries.

Additional information on price advantages in the respective countries can be drawn from fuel prices, which are the main input for fossil-fuel-fired power plants. Thus they are also the dominant factor influencing the variable costs of electricity generation. Concretely, acquisition costs have to be used representing the price that utilities have to pay for coal (CIF prices include costs, insurance and freight) as an input for electricity production. Following the IEA statistics 2007 on steam coal prices paid by utilities for electricity generation, it becomes clear that again the United States has a definitive price advantage over Japan and 
Germany. Not only did American utilities sometimes pay less then a third of what Japanese and German utilities had to pay, the price for steam coal in the US has also remained relatively stable. No data is available for China where the mining sector is state owned. Thus it can be concluded that the US has a price advantage in the global coal market.

\section{Demand advantage}

Indicators of a demand advantage are electricity intensity, the relevance of coal in national electricity production, and the average age of power stations.

Electricity demand provides information about the relevance of electricity within a particular country. It can be assumed that countries with high electricity consumption will also show a strong demand for new and efficient power plants. Following the IEA/OECD statistics (2007b), the USA consumes clearly the greatest amount of electricity among all nations analysed. In 2005 total final electricity consumption in the USA was 4,274,113 GWh, which means a per capita consumption of $14,129 \mathrm{kWh} / \mathrm{a}$. China may catch up in the future, since it rapidly transforms into an industrialised country and many of its inhabitants gain access to the electricity grid. In 2005 China was already the second largest energy consumer with 2,530,094 GWh, its per capita consumption was, however, still only 1,712 kWh/a. While Japan consumes almost twice the electricity of Germany, its per capita consumption is similar and constitutes roughly half of the electricity consumption in the USA.

The relevance of coal in national electricity production may be an indicator of possible lockin effects of the respective technologies. According to the IEA/OECD data (2007b), coal is relevant to the electricity production of all four countries, although there are differences between the economies. China shows an increasing share of coal in total electricity output. Starting with less than $60 \%$ in the late 1970 s, coal constituted $78 \%$ of the Chinese electricity production in 2005. The development in Germany, on the other hand, is the complete opposite: The share of coal decreased from $87 \%$ in 1960 to only $48 \%$ in 2005 . The USA shows a relatively stable share of coal in power generation of around $50 \%$. The development in Japan is on a comparatively low level, starting with $32 \%$ in 1960 , with a drop to $3.2 \%$ in 1975 and an increase to $24.7 \%$ in 2005 .

It is interesting to see that the countries in whose electricity sector coal played a smaller role (Japan, USA) were the ones identified as countries with the highest diffusion rates of coalfired power plant technology in section 4. This observation is not easy to explain, but one reason may be that countries where a technology is not dominating are less likely to have an 
infrastructure of existing power plants and thus need to build new ones.

This leads to the final indicator of demand advantage: the average age of power stations. Countries with a high average age of power stations are likely to replace their plants with new utilities in the near future, and vice versa. Thus it is an indicator of the urgent need for new investments, since coal-fired power plants are typically run for a period of 25 to 35 years. Yet it is possible to extend the operating time to 40 years and more. Nevertheless, an average age of 25 to 35 years has to be regarded as quite old, since it means that a huge share of the total capacity does not meet technical requirements and ought to be renewed. According to the World Electric Power Plant Database (WEPP 2007), the evidence is rather mixed. While all four countries have an increasing average age of coal-fired power plants, the highest figures can be observed for the USA (29.73 years in 2003), followed by Germany (21.67 years), Japan (15.96 years) and China (11.46 years).

Summing up, a demand advantage regarding actual electricity consumption can be derived for the USA, while in the future the leading position may switch to China. The indicators on the share of coal in total electricity production and on the average age of power stations do not provide clear answers.

\section{Transfer advantage}

Although a lead market is not necessarily the most innovative market, the degree to which research and development matters in a country is important for the transfer advantage, i.e. the question to what degree the country has a reputation as a lead market and is watched by other countries. It is generally justified to assume a positive correlation between the amount of $R \& D$ expenditures and the emergence and adoption of innovation designs. Countries spending more money on R\&D for coal-fired technologies than others will be regarded as competent and may be seen as trend-setters. According to the OECD data on GERD (Gross Expenditures for Research and Development) related to fossil fuels and coal-fired power plant technology in particular (IEA/OECD, 2007a), it can be observed that since the early 1980s, public R\&D has been cut back in all countries analysed in this study. In 2005 Japan spent $0.007 \%$ of its GDP on fossil fuel R\&D, the USA $0.0027 \%$ and Germany $0.0005 \%$. For China no comparable data exist.

Another relevant indicator is the number of demonstration plants in a country. Demonstration projects prove the practical relevance of innovations and the capability to translate theory into practice. Such technology has a good reputation since it has already been tested and is not 
affected by teething problems. This makes it easier to transfer the technology to other countries since the risks of investments and corresponding uncertainties are reduced. According to the database provided by the IEA (2007) Japan owns the highest number of demonstration plants (21), also per million capita (0.17), followed by Germany ( 8 and 0.1 ), USA (12 and 0.4) and China (9 and 0.00069).

Finally, the efficiency of coal-fired power plants is another indicator influencing the reputation of a country as a lead market. Looking at the IEA/OECD energy balances (2007b), all countries show a more or less recognisable upward trend in power plant efficiencies. In the 1950s and 1960s, the USA started out with the highest efficiency among the four countries, but it was surpassed by Japan in the 1970s. The USA did not manage to significantly increase the average efficiency of its coal-fired electricity plant fleet. In 1960, efficiency in the USA amounted to $33.9 \%$, in 2005 it was $36.4 \%$. Having turned almost entirely to oil for power generation before, Japan started to build a large number of new coal-fired electricity plants in the course of the oil price crisis in the 1970s. Today, Japan continues to be the country with the most efficient coal-fired electricity plants. For 2005 the indicator shows a degree of efficiency for Japan that averages $42 \%$.

Summing up, the indicators on the transfer advantage show a leading role of Japan.

\section{Export advantage}

The similarity of institutions and infrastructures between the exporting and importing country is an important determinant of an export advantage. When spreading new innovation designs across the globe, countries that are experienced in exporting technology will have advantages. The OECD International Trade Database (OECD, 2001) provides information on export and import figures for OECD members and important third countries for all commodities between 1990 and 2000. It can be seen that the highest number of power plant technology exports come from the USA, averaging \$ 23 bn in 2000. The USA is followed by Germany (11.5bn in 2000). The USA and Germany also export the highest number of supercritical and ultra supercritical power plants (see figure 8 and 9).

This it can be stated that the USA has an export advantage compared to the other countries under analysis.

\section{Market structure advantage}

There are forms of market structure which set higher incentives for innovations than others. 
Innovations are more likely to occur and to be tested in competitive markets than in monopolistic markets. We use the Global Competitiveness Index (GCI) provided by the World Economic Forum (2007). The indicator is, however, a general indicator for a country and not a specific indicator of sectoral regulation. In 2007/08 the USA is first ranked, Germany is ranked 5 th and Japan $8^{\text {th }}$. With state-owned companies still dominating large parts of its domestic economy, China is ranked $34^{\text {th }}$. Following this indicator, the USA has a market structure advantage over Germany and Japan, while China shows a clear disadvantage.

\section{Regulation advantage}

Along with the economic incentives of rising fuel prices and the technological development of other fossil fuel power plants, the political objective of reducing $\mathrm{CO}_{2}$ emissions is one of the main reasons why coal-fired power plant technology should be improved. The most common method to achieve $\mathrm{CO}_{2}$ reductions is the pricing of emissions. Countries that have committed themselves to carbon caps would therefore have a financial incentive to improve the efficiency of coal-fired power plants and to reduce carbon emissions. Since a worldwide price for $\mathrm{CO}_{2}$ emissions does not yet exist, the actual regulation advantage is difficult to quantify. We introduce a dummy which equals 1 whenever a country has committed itself to carbon caps and equals zero whenever a concrete reduction goal or carbon cap is missing. The Climate Change Performance Index conducted by Germanwatch (2007) informs about the actual situation regarding climate policy. According to this indicator, Japan and Germany (who have ratified the Kyoto Protocol) have a regulation advantage over the USA (who refused to ratify) and China (who has no $\mathrm{CO}_{2}$ constraints).

Moreover, countries follow different policies regarding renewable energies, which may have an impact on the development of coal technology. It can be assumed that countries which have a high proportion of electricity derived from renewable energy sources exert pressure on the coal sector and stimulate innovative, efficient and low-emission technologies for fossil fuels. An indicator would be the share of renewable energy sources in total electricity output as published by the IEA/OECD (2007b). According to this indicator, Germany has the highest proportion of renewables (in 2005). Its share of $7.4 \%$ is more than China, Japan and USA have together.

In total, it can be summarised that Germany has a regulation advantage compared to the other countries under analysis. 


\section{Conclusion}

The aim of this paper was to identify the relevant factors that have an impact on the emergence and diffusion of coal-fired power plants by applying the lead market model. SC and USC coal-based technology are two examples of emerging "clean coal" technologies that utilise coal more efficiently while generating fewer emissions. CFSC and CFUSC plants are especially diffusing in countries with rapidly evolving electricity demand such as China and India. However, CFSC and CFUSC plants diffused at the highest rate in Japan, where the technology makes up more than $90 \%$ of all coal-fired power plants installed. The USA has the largest coal reserves in the world and it is therefore very unlikely that American policy makers and American utilities will abandon this fossil fuel any time soon.

What is also striking is the high degree of internationalisation of the power plant technology market. No country obtains its power plants exclusively from domestic companies. Especially China, Germany and South Korea turn to foreign companies for supercritical and ultra supercritical power plants. It is remarkable that - at least for the coal sector - China does not obtain one single SC or USC plant from domestic suppliers but relies almost entirely on European firms. All in all, we can state that the USA seems to be the most innovative market, while Japan lags only slightly behind in terms of innovativeness, but shows higher adoption rates. Germany is innovative but less adoptive than the USA and Japan. As a developing country with low electricity demand per capita and low GDP per capita, China relies entirely on foreign companies when it comes to the R\&D and production of "clean coal" technology. However, the enormous increase in Chinese electricity demand and the great size of the country will result in relatively high absolute figures of installed CFSC and CFUSC plants, although the ratio of installed "clean coal" technology per capita is still extremely low compared to the other three countries.

After analysing the technology diffusion in the four countries, one central question evolves: Can we determine a lead market for coal-fired power plant technology today? A closer look at the different lead market factors gives us the following answer: It can be concluded from the discussion of lead market factors in section 5 that no clear lead market exists for coal-fired power plant technology. Although the United States still has comparative advantages in terms of prices, demand and market structure, Japan has caught up in terms of transfer advantage and Germany in terms of regulation. In the near future, demand advantages will switch to China.

This supports also the thesis that - apart from the demand-oriented lead market model - push 
factors such as R\&D activity play a strong role as well. The transfer advantage of Japan stems mainly from its intensive R\&D activities. Thus it can be concluded that a mix of push and pull policies is necessary in order to establish a lead market position.

\section{Acknowledgements}

Funding from the Volkswagen Foundation within the project "The Significance of Germany as a Site for Power Plant Construction against the Background of an Increasing Internationalization of Innovation Processes" is warmly appreciated. We would like to thank Stefan Vögele and Peter Markewitz from the Forschungszentrum Jülich, Institut für Energieforschung - Systemforschung und Technologische Entwicklung (IEF-STE) for providing data, and our colleagues Tim Hoffmann and Sebastian Voigt for fruitful discussions.

\section{References}

Alstom (2007), Annual Report 2006/07, August $13^{\text {th }} \quad 2007$ : http://www.alstom.com/home/investors/publications/index.EN.php?languageId=EN\&dir=/h ome/investors/publications/

Bartlett, Ch., Ghoshal (1990), Managing innovation in the transnational corporation, in: Bartlett Ch., Y. Doz, G. Hedlund (eds), pp. 215- 255.

Beise, M. (2001), Lead Markets. Country-Specific Success Factors of the Global Diffusion of Innovations, ZEW Economic Studies Vol. 14, p. 7, Heidelberg/New York.

Beise, M., K. Rennings (2005), Lead markets and regulation: a framework for analyzing the international diffusion of environmental innovations, Ecological Economics Vol. 52, p. 7.

Beise-Zee, R., C. Rammer (2005), The concept of "lead markets": a literature overview, European Competitiveness Report 2005, Background report.

Dekimpe, M. G., P. M. Parker, and M. Sarvary (1998), “Globalisation”: Modelling Technology adoption Timing across Countries, INSEAD working paper No. 98/69/MKT.

Dosi, G., K. Pavitt, and L. Soete (1990), The Economics of Technical Change and International Trade, New York, Harvester Wheatsheaf.

Germanwatch (2007), Climate Change Performance Index 2008, http://www.germanwatch.org/ccpi.htm 
Gort, M., S. Klepper (1982), Time Paths in the Diffusion of Product Innovations, Economic Journal Vol. 92, pp. 630-653.

IEA (2004) (International Energy Agency), Energy Statistical Manual, OECD/IEA, Paris.

IEA (2006) (International Energy Agency), World Energy Outlook - 2007, OECD/IEA, Paris.

IEA (2007a) (International Energy Agency), Coal Information, OECD/IEA, Paris.

IEA (2007b) (International Energy Agency), Clean Coal Technology, December $1^{\text {st }} 2007$, http://www.iea-coal.org.uk/content/default.asp?PageId=988

IEA (2007c) (International Energy Agency), CoalPower Database, OECD/IEA, Paris

IEA/OECD (2007a) International Energy Agency, Organization for Economic Cooperation and Development, 2007, Energy Technology R\&D, RDD budgets Vol 2007(01), Paris.

IEA/OECD (2007b) International Energy Agency, Organization for Economic Cooperation and Development, 2007, Energy balances of OECD countries 1960-2005, Paris.

Lako, P. (2004), Coal-fired power technologies - Coal fired power options on the brink of climate policies, Energy research Centre of the Netherlands, November $6^{\text {th }} 2007$, http://www.ecn.nl/docs/library/report/2004/c04076.pdf

Levitt, T. (1983), The Globalisation of Markets, Harvard Business Review Vol. 61 (3), pp. 92102.

Mahajan, V., E. Muller and F.M. Bass (1990), New Product Diffusion Models in Marketing: a Review and Directions for Research, Journal of Marketing Vol. 77, pp. 531-558.

Mansfield, E. (1968), Industrial Research and Technological Innovation: An Econometric Analysis, New York, Norton.

Nelson, R. R., S. G. Winter (1977), In Search of Useful Theory of Innovation, Research Policy, 6 (1), January, 37-76.

Nelson , R. R. (1959), The Economics of Invention: A survey of the literature, Journal of Business, XXXII (2), April, $101-127$.

Meyer-Krahmer, F. et al. (1998), Internationalisation of Research and Technology: Trends, Issues and Implications for S\&T Policies in Europe, Brussels, Belgium: European Commission ETAN Papers Collection. 
OECD (2001) Organization for Economic Cooperation and Development, ITCS International Trade by Commodity Database, Harmonized System 1998, Paris.

Porter, M. E. (1990), The Competitive Advantage of Nations, New York: Free Press.

Posner, M. V. (1961), International Trade and Technical Change, Oxford Economic Papers 30, 323-341.

Prognos (2007), The future role of coal in Europe, Euracoal, January $29^{\text {th }} 2008$ : http://euracoal.be/newsite/prognos_FutureCoal_070822 final_kurz.pdf

Seydel, P., M. Wietschel (2005), Report on the Lead market approach and the input/output analysis of energy systems on all branches of industry, Deliverable of work package 3 in the scope of The Development and Detailed Evaluation of an Harmonized "European Hydrogen Energy Roadmap" under FP6, p. 5.

Tellis, G., S. Stremersch , and E. Yin (2003), The International Takeoff of New Products: The Rrole of Economics, Culture, and Country Innovativeness, Marketing Science Vol. 22., pp. 188-208.

Utterback, J.M. (1994), Mastering the Dynamics of Innovation, Boston: Harvard Business School Press.

Vernon, R. (1979) The Product Cycle Hypothesis in a New International Environment, Oxford Bulletin of Economics and Statistics Vol. 41 (4), pp. 255-267.

WCI 2005 (World Coal Institute) (2005), The Coal Resource, 15 November 2007: http://www.worldcoal.org/pages/content/index.asp?PageID=37

WEC 2007 (World Energy Council) (2007), Survey of Energy Resources, World Energy Council, London.

World Economic Forum (2007), World Economic Forum, 2007, Global Competitiveness report 2007/2008, http://www.gcr.weforum.org

Yip, G. S. (1992), Total Global Strategy: Managing for Worldwide Competitive Advantage, Englewood Cliffs: Prentice-Hall. 